\title{
Break-down of Losses in High Performing Metal-Supported Solid Oxide Fuel Cells
}

\author{
Kromp, Alexander; Nielsen, Jimmi; Blennow Tullmar, Peter; Klemensø, Trine; Weber, André
}

Published in:

Proceedings of the 10th European SOFC Forum

Publication date:

2012

Link back to DTU Orbit

Citation (APA):

Kromp, A., Nielsen, J., Blennow Tullmar, P., Klemensø, T., \& Weber, A. (2012). Break-down of Losses in High Performing Metal-Supported Solid Oxide Fuel Cells. In Proceedings of the 10th European SOFC Forum (pp. 8494). European Fuel Cell Forum.

\section{General rights}

Copyright and moral rights for the publications made accessible in the public portal are retained by the authors and/or other copyright owners and it is a condition of accessing publications that users recognise and abide by the legal requirements associated with these rights.

- Users may download and print one copy of any publication from the public portal for the purpose of private study or research.

- You may not further distribute the material or use it for any profit-making activity or commercial gain

- You may freely distribute the URL identifying the publication in the public portal

If you believe that this document breaches copyright please contact us providing details, and we will remove access to the work immediately and investigate your claim. 


\title{
Break-down of Losses in High Performing Metal- Supported Solid Oxide Fuel Cells
}

\author{
Alexander Kromp (1), Jimmi Nielsen (2), Peter Blennow (2), Trine Klemensø (2), \\ André Weber (1) \\ (1) Institut für Werkstoffe der Elektrotechnik (IWE), Karlsruher Institut für Technologie (KIT) \\ Adenauerring 20b, 76131 Karlsruhe, Germany \\ (2)Department of Energy Conversion and Storage, Technical University of Denmark \\ Frederiksborgvej 399, DK-4000 Roskilde, Denmark \\ Tel.: +49-721-608-47570 \\ Fax: +49-721-608-47492 \\ alexander.kromp@kit,edu
}

\begin{abstract}
Metal supported SOFC designs offer competitive advantages such as reduced material costs and improved mechanical robustness. On the other hand, disadvantages might arise due to possible corrosion of the porous metal parts during processing and operation at high fuel utilization.

In this paper we present the results of performance and stability improvements for a metal supported cell developed within the European project METSOFC and the Danish National Advanced Technology Foundation. The cells consist of a porous metal backbone, a metal / zirconia cermet anode and a 10ScYSZ electrolyte, cofired in hydrogen. The electrochemically active parts were applied by infiltrating CGO-Ni precursor solution into the porous metal and anode backbone and screenprinting ( $\mathrm{La}, \mathrm{Sr})(\mathrm{Co}, \mathrm{Fe}) \mathrm{O}_{3}$-based cathodes. To prevent a solid state reaction between cathode and zirconia electrolyte, CGO buffer layers were applied in between cathode and electrolyte.

The detailed electrochemical characterization by means of impedance spectroscopy and a subsequent data analysis by the distribution of relaxation times enabled us to separate the different loss contributions in the cell. Based on an appropriate equivalent circuit model, the ohmic and polarization losses related to the gas diffusion in the metal support, the electrooxidation in the anode functional layer and the oxygen reduction in the mixed ionic electronic conducting cathode were determined. An additional process with a rather high relaxation frequency could be attributed to the formation of insulating interlayers at the cathode/electrolyte-interface. Based on these results, selective measures to improve performance and stability, such as (i) an improved PVD-deposited CGO buffer layer, (ii) LSC-CGO based in-situ sintered cathodes and (iii) reduced corrosion of the metal support were adopted and validated.
\end{abstract}




\section{Introduction}

Metal supported SOFC stack technology are believed to offer an alternative to conventional electrode- and electrolyte-supported SOFCs. They have many potential advantages such as good thermal conductivity and ductility of the metallic substrate, which may both improve thermal shock resistance, and lower the internal temperature gradients, allowing quicker start-up [1]. If successful, metal-based SOFC stack technologies have the potential to improve functionality, reliability and reproducibility and reduce the manufacturing cost of SOFC stacks [2], in particular for APU applications which require:

- fast start-up and thermal cycling

- $\mathrm{CO}$ and hydrocarbon rich fuels

- high current density

- shock vibration resistance

- fast transients in electrical loads

- red-ox cycling

Since metal supported SOFCs have an intrinsically different mechanical behavior, compared to ceramic components, it makes them potential candidates for withstanding the mechanical stresses e.g. generated by the severe vibrations when a stack is incorporated into systems used for transport applications. Despite these potential advantages, the cell fabrication process has been one of the major challenges holding back the development of metal supported SOFCs. One of the most important issues is the densification of the electrolyte layer that normally requires high sintering temperatures (> $1200^{\circ} \mathrm{C}$ for YSZbased electrolytes). These high temperatures tend to lead to serious corrosion of the metallic substrate. To solve the problem, different processing routes to fabricate electrodes and dense electrolytes on metallic supports have been employed, such as atmospheric plasma spray processing (APS) [3], vacuum plasma spraying (VPS) [4], suspension plasma spraying [5], high-velocity oxy-fuel (HVOF) spraying of liquid suspension feedstock [6], pulsed laser deposition (PLD) [7] and high temperature co-sintering in reducing atmosphere $[1 ; 8 ; 9]$.

DTU Energy Conversion (part of former Risø DTU, hereafter referred to as DTU) has developed an unconventional cell design based on porous and highly electronically conducting layers into which electrocatalytically active anode materials (CGO and minor amounts of $\mathrm{Ni}$ ) are infiltrated after sintering [10]. This paper presents the performance and stability of these cells and their detailed electrochemical analysis.

\section{Experimental}

In this study, two types of metal supported cells, type A and type B have been investigated. There are three main differences:

- The substrate morphology: To minimize corrosion of the metal support, the type B substrate exhibits a coarser microstructure with a reduced internal surface area.

- The composite cathode: Whereas the type A cells exhibited a LSCF-CGO cathode, a LSC-CGO cathode was applied in the type B cells.

- The CGO (CGO: $\mathrm{Gd}_{2} \mathrm{O}_{3}$ doped $\mathrm{CeO}_{2}$ ) interdiffusion barrier layer in between the cathode and the ScYSZ electrolyte: Whereas type A cells exhibited a direct contact in between the LSCF-CGO cathode and ScYSZ electrolyte, the ScYSZ electrolyte of the type B cells was coated with a CGO interdiffusion barrier layer [11]. 
All cells were fabricated using the same procedures as described in previous publications $[11 ; 12]$. Cross-sectional micrographs of the two different types of half cells after sintering (before infiltration and testing) are depicted in Figure 15. The micrographs show that the employed fabrication route gives a metal support layer and a cermet layer that seem sufficiently porous for gas transport as well as a dense electrolyte layer meeting the requirements of gas tightness. The substrate of cell type $\mathrm{B}$ exhibits a coarser microstructure, which is advantageous with respect to corrosion.

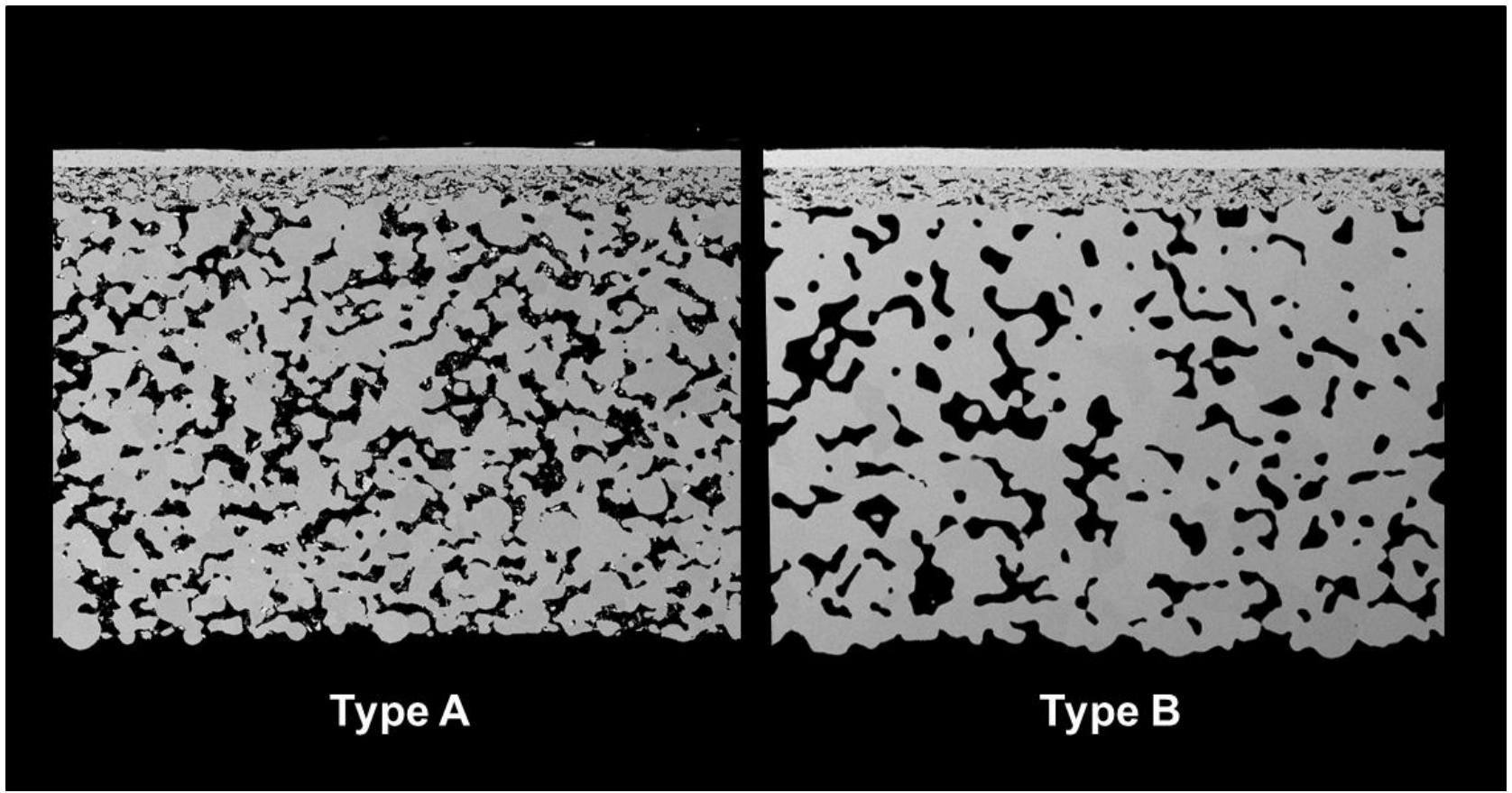

Figure 15: SEM micrograph showing representative cross-sections of type $A$ and type $B$ half cells (i.e. no cathode or contact layer printed).

At IWE single cells of type $A$ and $B$ with an active electrode area of $1 \mathrm{~cm}^{2}$ were tested in a setup as described in [13]. The cells were characterized by CV-characteristics at different simulated fuel utilizations (fuel: hydrogen, 5 to $80 \% \mathrm{H}_{2} \mathrm{O}$ ) and a detailed impedance analysis [14]. Impedance spectra were measured in a temperature range from 500 to $750{ }^{\circ} \mathrm{C}$, at varied oxidant $\left(p \mathrm{O}_{2, \text { cat }}=0.21-0.025\right.$ atm $)$ and fuel composition $\left(\mathrm{H}_{2}+\mathrm{H}_{2} \mathrm{O}\right.$, $\left.\mathrm{pH}_{2} \mathrm{O}_{\mathrm{an}}=0.05-0.85 \mathrm{~atm}\right)$. The measurements were performed under OCV conditions in a frequency range from $10 \mathrm{mHz}$ to $10 \mathrm{MHz}$. The impedance data analysis was performed by calculating the distribution of relaxation times [15] and a subsequent fitting of the impedance spectra to a physically meaningful equivalent circuit.

\section{Results and Discussion}

First results of a detailed electrochemical characterization of the type $A$ cells have been presented at the last meeting $[10 ; 16]$. In this paper the characteristics of the type $B$ cell are presented and compared with type A.

In order to obtain information about the electrochemical processes and their parameter dependencies, type $\mathrm{B}$ cells were tested under variation of the partial pressure of steam at the anode $\left(\mathrm{pH}_{2} \mathrm{O}_{\mathrm{an}}\right)$ and the partial pressure of oxygen at the cathode $\left(p \mathrm{O}_{2, \text { cat }}\right)$. The distribution of relaxation times (DRT) method [15] and the subsequent CNLS- fitting of a physically motivated equivalent circuit [17] were applied to obtain an accurate electrochemical analysis of the measured cells. 


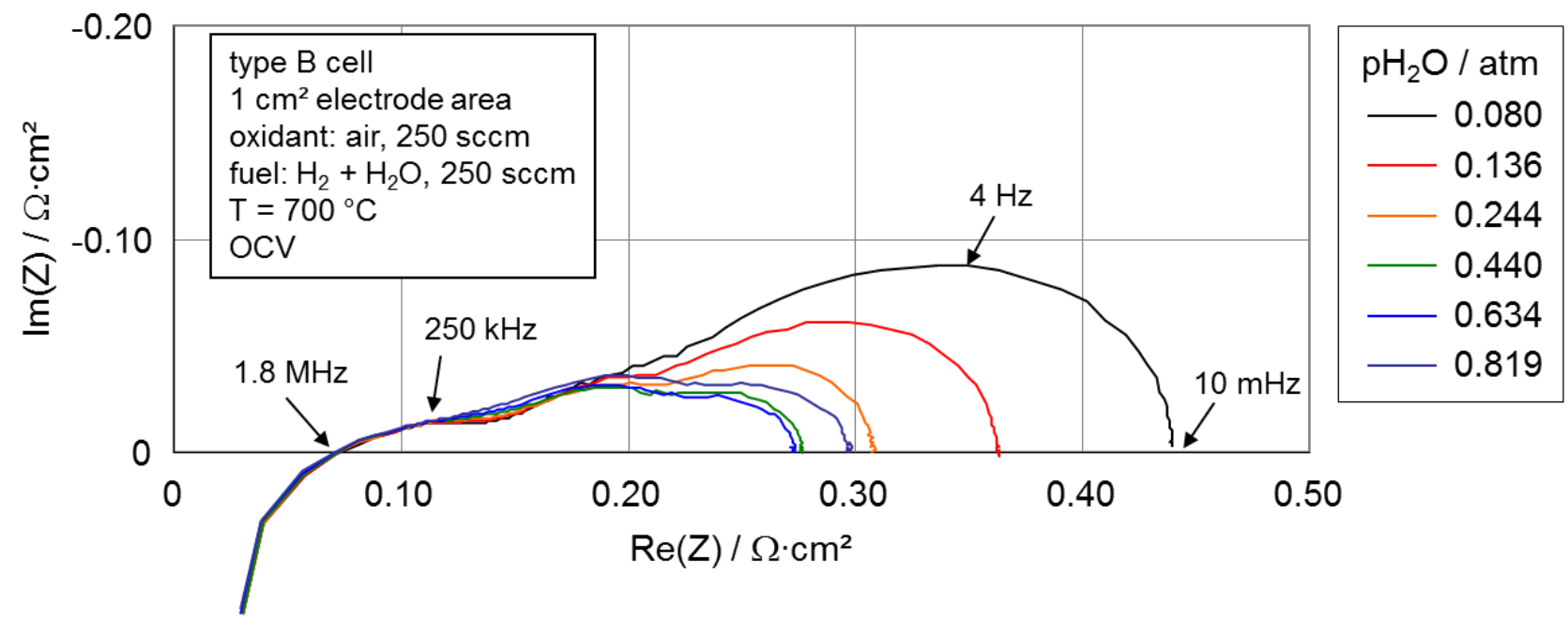

Figure 16: Series of impedance spectra recorded under variation of the steam partial pressure at the anode.

Figure 16 displays impedance spectra recorded for varied $p \mathrm{H}_{2} \mathrm{O}_{\text {an }}$. The low-frequency arcs of the spectra show a significant sensitivity to the variation of $p \mathrm{H}_{2} \mathrm{O}_{a n}$, whereas the highfrequency arcs exhibit a low sensitivity. At high frequencies (above $1 \mathrm{MHz}$ ), inductances caused by the wiring in the test setup become visible. However it can be seen clearly that there is at least one polarization process in this high frequency range. Due to the overlapping of the high-frequency process(es) and the inductance of the wiring in the test setup, the measured data in the frequency range of $10 \mathrm{mHz}$ to $250 \mathrm{kHz}$ were considered for the DRT-analysis and the equivalent circuit-fitting.

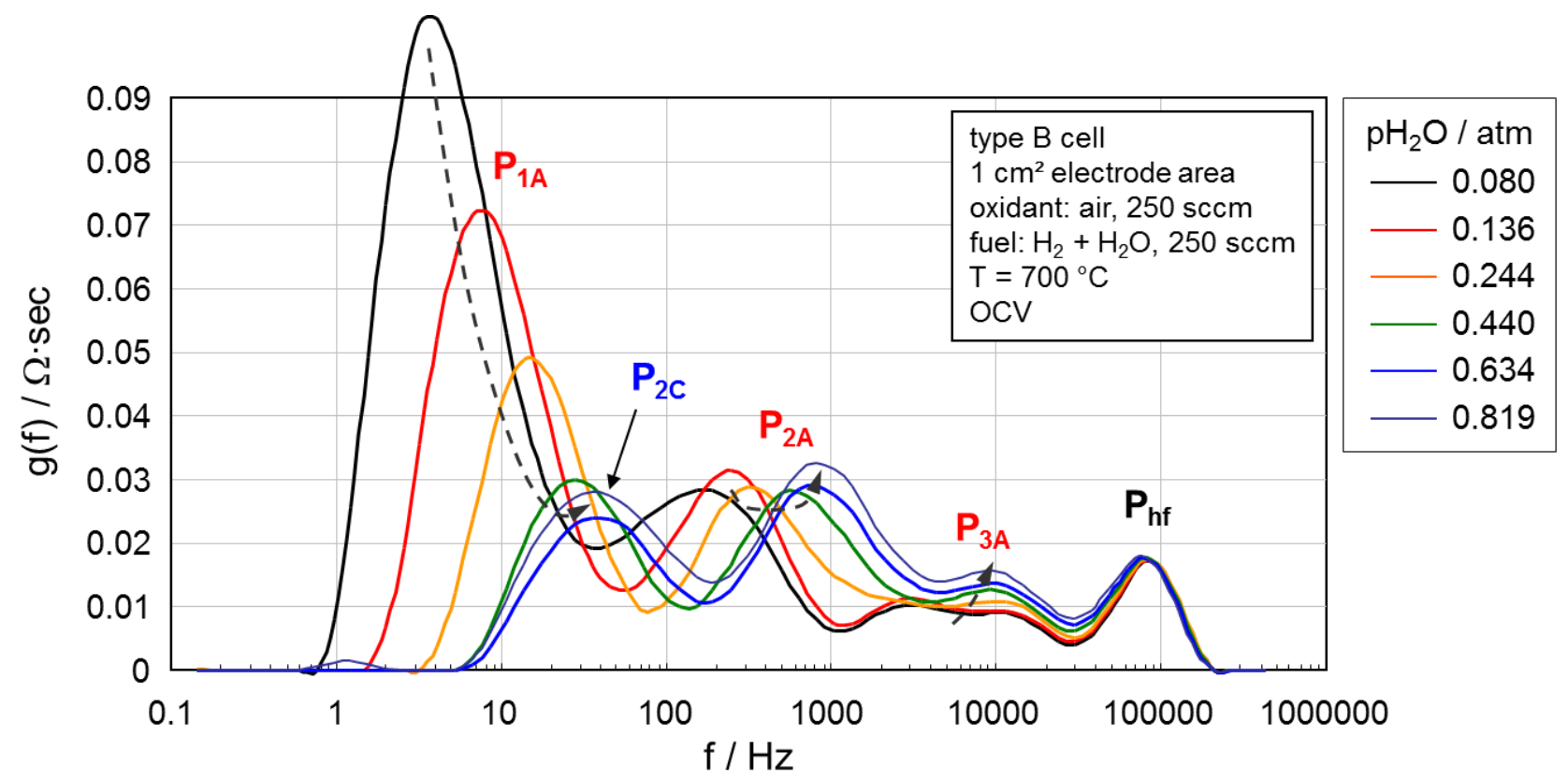

Figure 17: Series of DRT's calculated for the impedance spectra measured at varied $\mathrm{pH}_{2} \mathrm{O}_{a n}$.

In Figure 17, the DRT for the measured spectra given in Figure 16 are displayed. As for type A cells [10] the polarization processes attributed to the gas diffusion within the anode and the metal support $\left(P_{1 \mathrm{~A}}\right)$ and to the electrochemistry at the anode $\left(P_{2 \mathrm{~A}}\right.$ and $\left.P_{3 \mathrm{~A}}\right)$ were also identified for type $B$ cells. For both cell types, the anodic processes were in the same 
frequency ranges and showed the same characteristic dependency on the steam partial pressure at the anode. At high frequencies, a polarization process $\left(P_{\mathrm{hf}}\right)$, which does not exhibit sensitivity to the variation of $\mathrm{pH}_{2} \mathrm{O}_{a n}$, is visible.

In order to identify the polarization processes occurring at the cathode, impedance spectra were recorded under a variation of the partial pressure of oxygen at the cathode. Figure 18 displays the corresponding DRTs. The two cathode polarization processes found for type A cells, were found for the type $B$ cells too. They are related to the gas diffusion within the cathode $\left(P_{1 \mathrm{C}}\right.$, only for low $p \mathrm{O}_{2, \text { cat }}<0.21 \mathrm{~atm}$ at low relaxation frequencies) and the oxygen reduction in the mixed ionic electronic conducting cathode $\left(P_{2 \mathrm{C}}\right)$ in the relaxation frequency range of 10 to $100 \mathrm{~Hz}$.

The high-frequency polarization processes, which neither showed any sensitivity to $\mathrm{pH}_{2} \mathrm{O}_{a n}$ nor to $\mathrm{pO}_{2, \text { cat }}$, were found in the spectra of both types of cells.

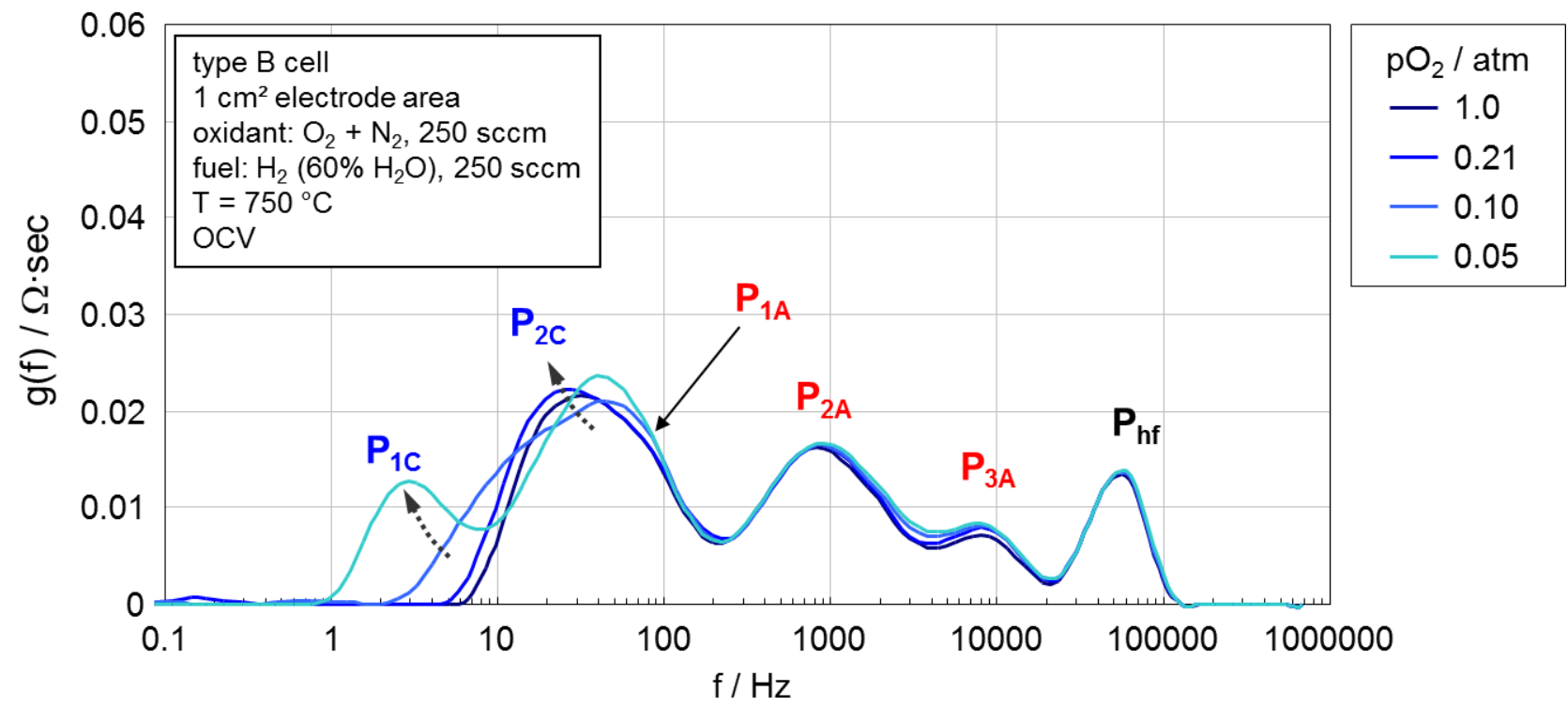

Figure 18: Series of DRT's calculated for the impedance spectra measured at varied $p \mathrm{O}_{2, \text { cat }}$.

Based on these findings, the equivalent circuit model developed for type A cells [10] was applied for a quantitative analysis of the single polarization processes. Whereas for the type A cells two high frequency polarization processes could be resolved [10;16], the type B cells exhibited only one process in this frequency range. The high frequency process $P_{\text {hf }}$ was not considered in the model applied for the fit. To quantify the ASR related to this process, the resistance of the electrolyte was calculated from the conductivity of the applied electrolyte material and the electrolyte thickness of the corresponding cell. Hence, the area specific resistance (ASR) of the high-frequency process was determined by subtracting the calculated ASR from the ohmic resistance obtained through the equivalent circuit fit.

Figure 19 shows the Arrhenius plot of the polarization resistances of $P_{\mathrm{hf}, 1}$ and $P_{\mathrm{hf}, 2}$ of the type A cell in comparison with $P_{\mathrm{hf}}$ of the type B cell. The comparison demonstrates clearly that the high frequency polarization process $P_{\mathrm{hf}}$ found for type $\mathrm{B}$ cells corresponds to the high frequency polarization process $P_{\mathrm{hf}, 2}$ of the type A cell. Both area specific resistance and activation energy show an excellent agreement. The high frequency process $P_{\mathrm{hf}, 1}$, which is dominating the overall losses of the type A cell, does not occur for type B cells. 


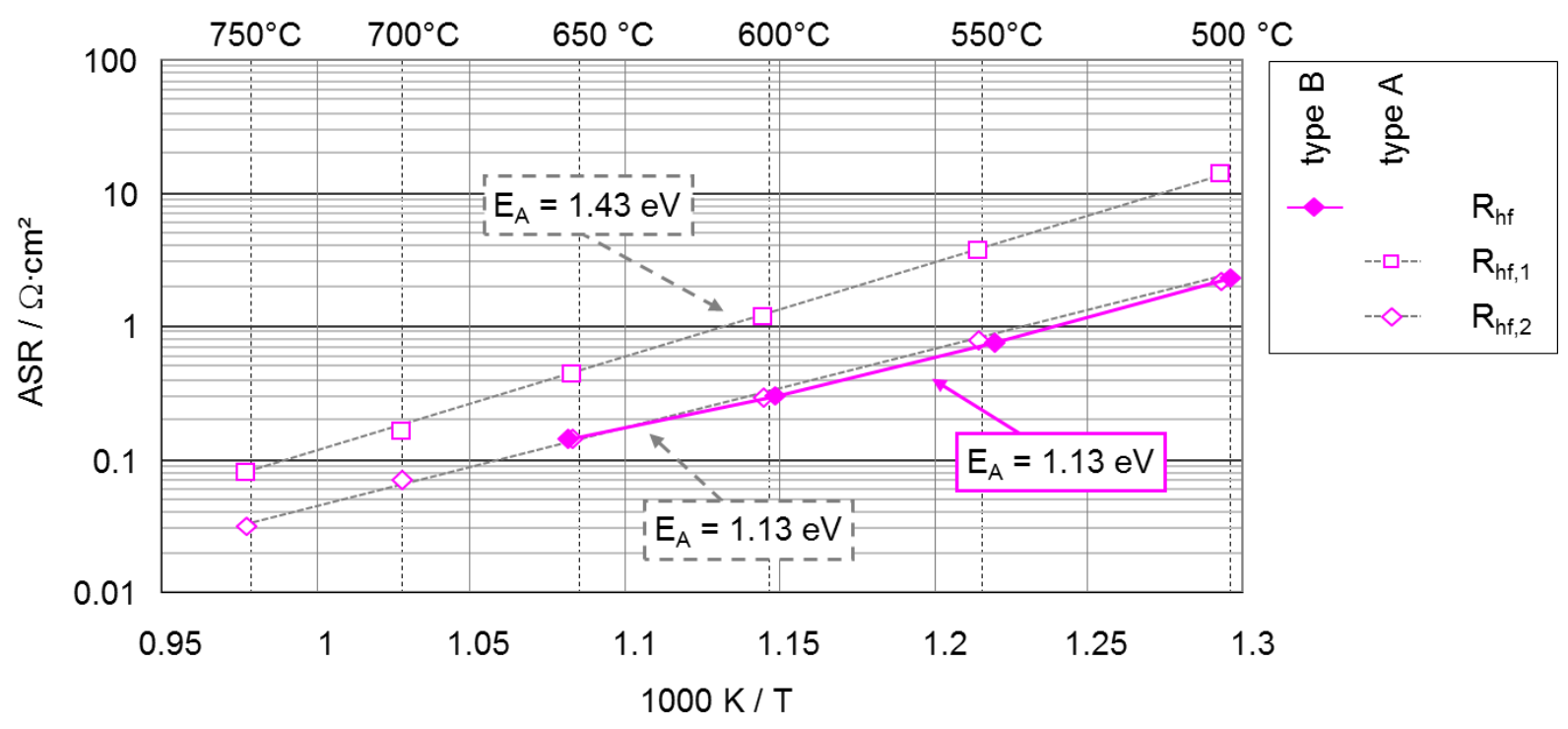

Figure 19: Temperature dependency of the high frequency polarization processes of type $A$ and type $B$ cells.

Considering the different cathode structures of type A (LSCF/CGO on 10ScYSZ) and type B cells (PVD-CGO-interlayer in between MIEC-cathode and zirconia electrolyte), it is most likely that $P_{\mathrm{hf}, 1}$ might be related to a zirconate layer formed at the cathode/electrolyteinterface, which is prevented in case of a PVD-CGO-interlayer [11].

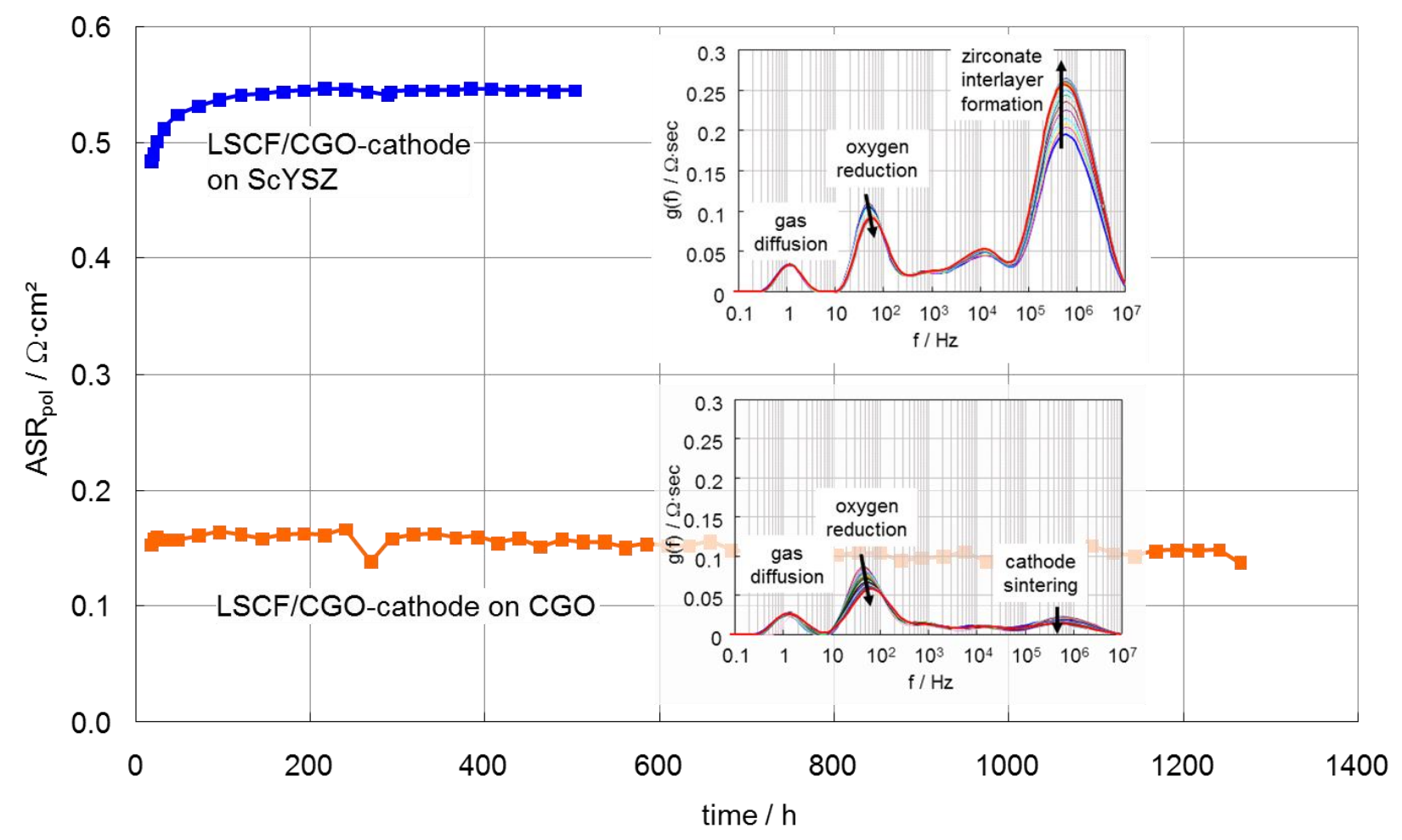

Figure 20: Polarization resistance $\left(R_{h f}+R_{1 C}+R_{2 C}\right)$ of LSCF/CGO-cathodes on SCYSZ and CGO electrolyte substrate $\left(T=650^{\circ} \mathrm{C}\right.$, air $)$. 
To prove this, symmetrical cathode cells with similar cathode layers on a ScYSZ and a CGO electrolyte substrate respectively were tested. Figure 20 shows the polarization resistance vs. time. In case of a ScYSZ substrate a much higher polarization resistance was observed. The DRT of the impedance spectra revealed an increasing high frequency polarization process, which was not observed in case of the CGO-electrolyte.

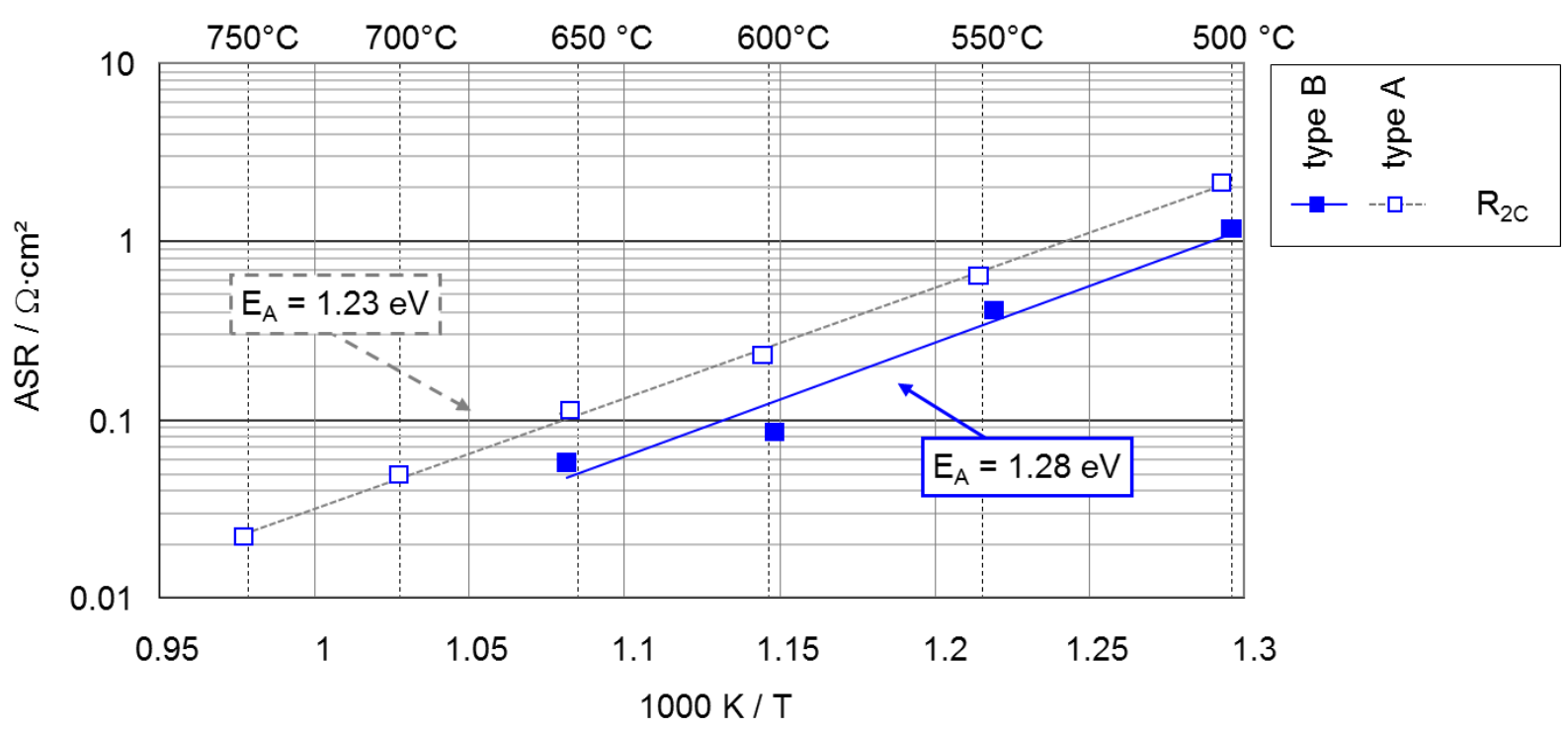

Figure 21: Arrhenius plot of the cathode activation polarization.

In Figure 21 the cathode activation polarization resistance $R_{2 C}$ is displayed for the type $A$ and the type B cell. The comparison shows that the ASR of the cathode of the type B cell is by factor 0.5 lower. The activation energies for the cathode of both cells $\left(E_{A, t y p e A}=1.23 \mathrm{eV}, E_{A, t y p e B}=1.28 \mathrm{eV}\right)$ are in the same range. The improved cathode performance of type $B$ cells has to be attributed to the cathode composition (type B: LSC/CGO, type A: LSCF/CGO) and might also be attributed to the dense CGO-interlayer in between cathode and ScYSZ electrolyte. Previous studies on anode supported cells revealed, that a high quality CGO interdiffusion barrier layer improves surface exchange and bulk diffusion properties in the porous cathode layer. This was related to a lowered loss of Sr, which is otherwise "consumed" for the formation of the $\mathrm{SrZrO}_{3}$-layer.

Figure 22 gives the Arrhenius plot of the anodic polarization resistances of type $A$ and type $B$ cells. As both cells exhibit quite similar anode functional layers the ASR-contribution of $P_{2 A}$ and $P_{3 A}$ is quite similar. The determined activation energies for the type $\mathrm{B}$ cell $\left(E_{A}=0.91 \mathrm{eV}\right)$ is lower than the value of the type $A$ cell $\left(E_{A}=1.34 \mathrm{eV}\right)$. It has to be stated that the ratio of the applied materials for the anode functional layer (FeCr/YSZ) are slightly different for type $A$ and type $B$ cells. The different activation energies determined for both cell types are very likely to be attributed to the different ratios of electronic conducting phase (FeCr) and ionic conducting phase (YSZ) in both cell types.

The comparison of $\mathrm{P}_{1 \mathrm{~A}}$ shows that the area specific resistance of the anode gas diffusion polarization process $\left(R_{1 \mathrm{~A}}\right)$ is virtually the same for both types of cells. Despite of the coarser microstructure and lower porosity of the substrate of cell type B (Figure 15), resulting in an improved corrosion behavior, a similar performance could be achieved. 


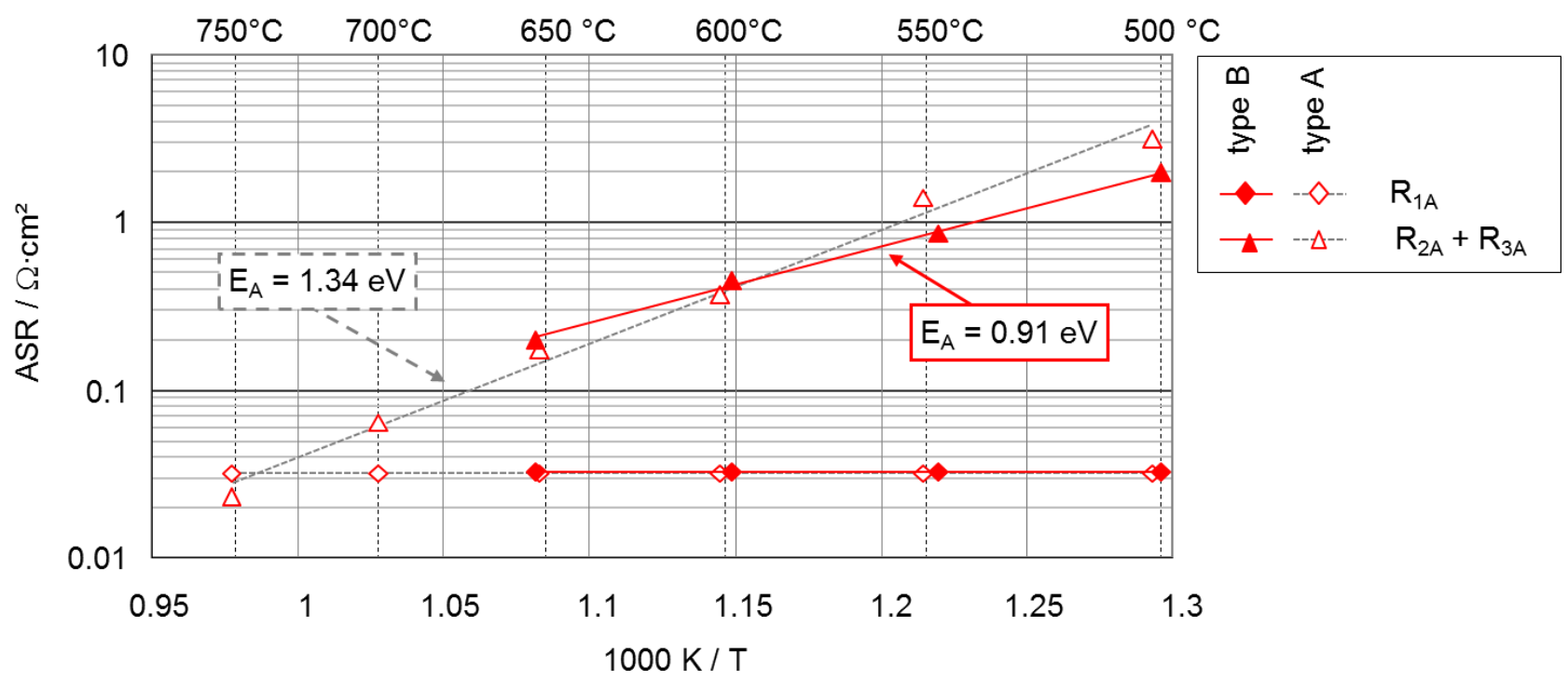

Figure 22: Arrhenius plot of the anode polarization resistances.

In Figure 23(a) the $p \mathrm{H}_{2} \mathrm{O}_{\text {an }}$ dependency of anode activation polarization resistance $R_{\text {act,an }}=$ $R_{2 \mathrm{~A}}+R_{3 \mathrm{~A}}$ is displayed. It is interesting that the polarization processes related to the charge transfer reaction at the anode exhibit an increasing resistance for increasing $\mathrm{pH}_{2} \mathrm{O}_{\text {an }}$. The anodic activation polarization processes $P_{2 \mathrm{~A}}$ and $P_{3 \mathrm{~A}}$ are formed by the complex coupling of ionic transport, gas transport and the electrochemical fuel oxidation [17]. For cermet anodes, it has been shown that these processes decrease with increasing $\mathrm{pH}_{2} \mathrm{O}_{\text {an }}$.

(a)

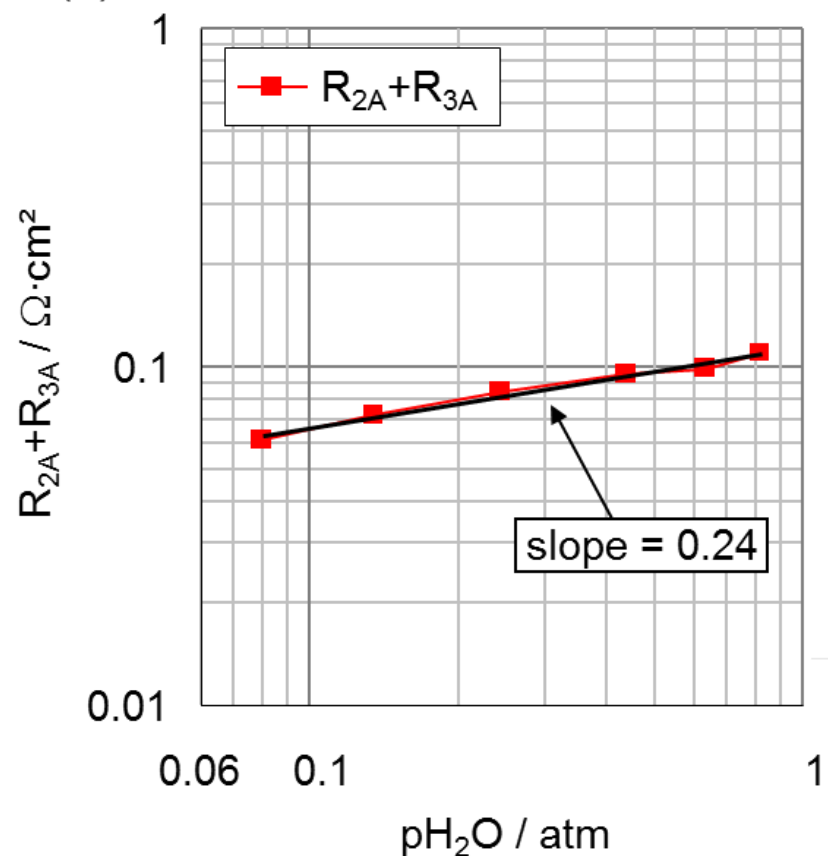

(b)

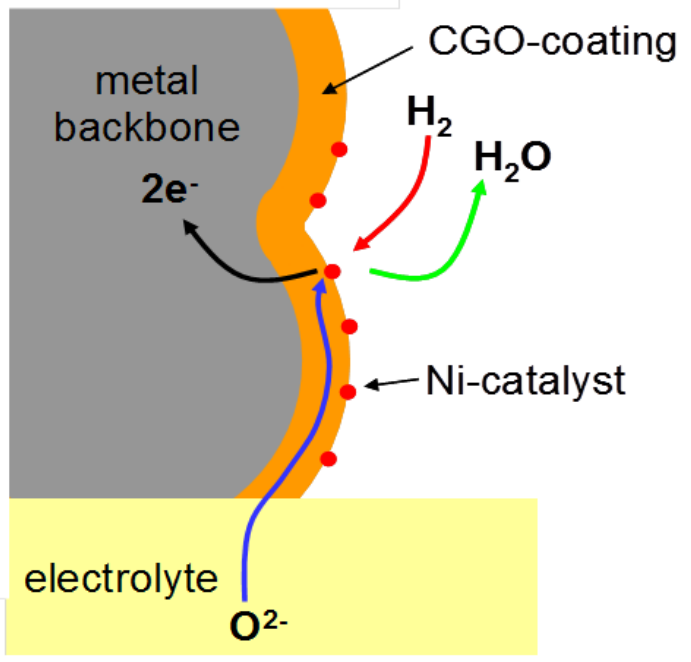

Figure 23: (a) $\mathrm{pH}_{2} \mathrm{O}$-dependency of the anode activation polarization resistance $\left(\mathrm{R}_{2 \mathrm{~A}}+\mathrm{R}_{3 A}\right)$. (b) Scheme of the METSOFC-anode. 
As for cermet anodes, the linear trend in the double-logarithmic plot is clearly visible, too. However, the slope of 0.24 is dramatically different from values found for cermet anodes (0.33 [18]). This behavior can be explained with the scheme of the METSOFC-anode given in Figure 23b. The electronic conductivity of the CGO-coating decreases with increasing $\mathrm{pH}_{2} \mathrm{O}_{\text {an }}$, which most probably causes the rise in resistance of the overall anode activation polarization process.

A breakdown of the losses contributions is given in Figure 24. The plot shows the individual area specific resistance contributions for type $A$ and type $B$ cells. Under the given operating conditions (cathode: air, $250 \mathrm{sccm}$; anode: $\mathrm{H}_{2}\left(60 \% \mathrm{H}_{2} \mathrm{O}, 250 \mathrm{sccm}\right.$; $\mathrm{T}=$ $650^{\circ} \mathrm{C}$; OCV), the type B cell $\left(478 \mathrm{~m} \Omega \cdot \mathrm{cm}^{2}\right)$ shows a much lower total resistance than the type A cell $\left(920 \mathrm{~m} \Omega \cdot \mathrm{cm}^{2}\right)$. This improvement has to be mainly ascribed to the CGO interlayer between the electrolyte and the MIEC-cathode, which prevents the formation of an insulating zirconate phase. The corresponding polarization resistance of $427.5 \mathrm{~m} \Omega \cdot \mathrm{cm}^{2}$ does not occur on the type $B$ cells. It is also worth to mention that the cathode activation polarization of the type $B$ cells has improved significantly due to the application of a LSC/CGO-composite instead of a LSCF/CGO-composite. The corresponding resistance has been decreased by $50 \%$.

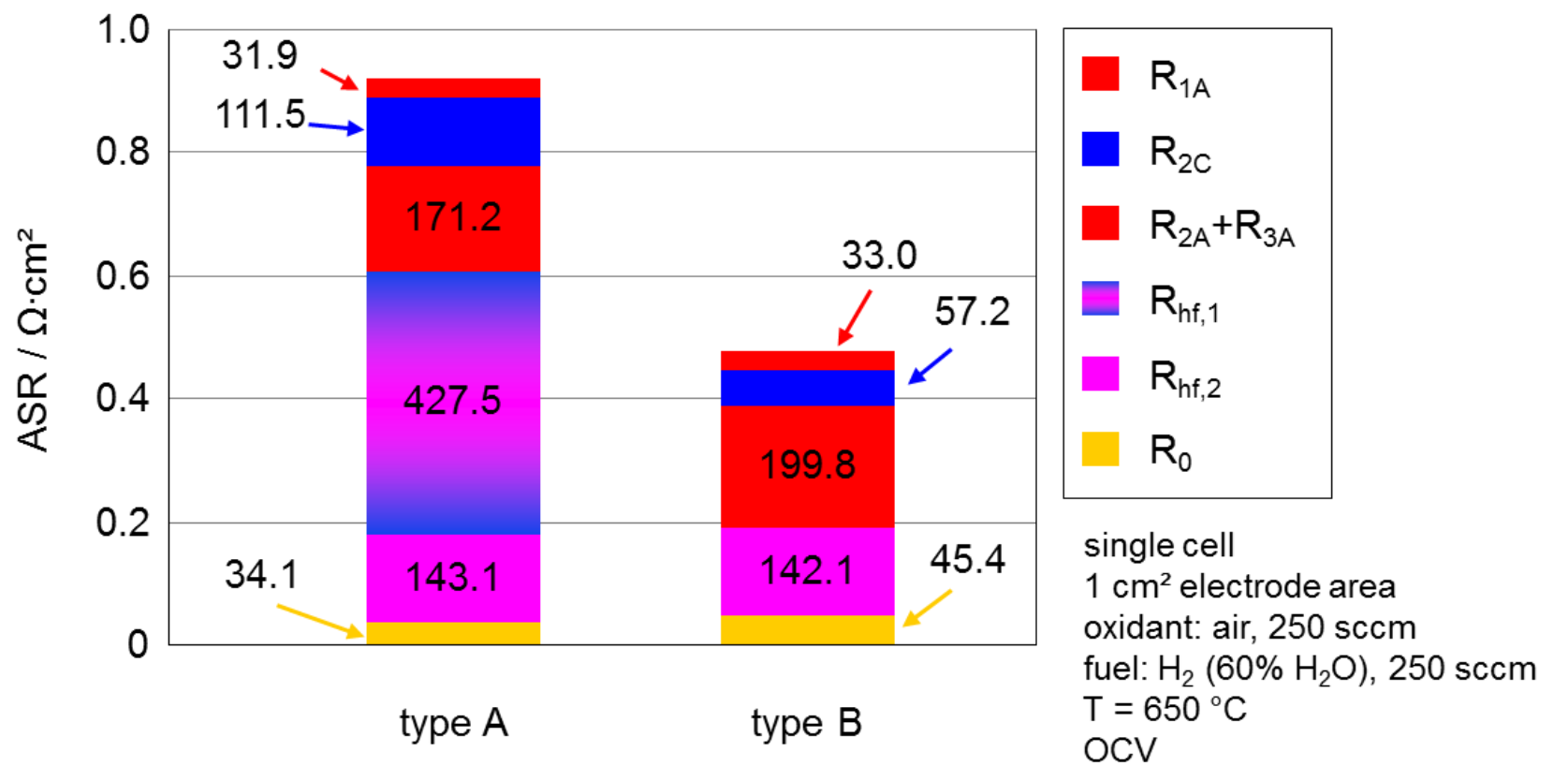

Figure 24: Comparison of the single loss contributions of type $A$ and type $B$ cells. 


\section{Conclusions}

A metal supported SOFC design developed within the European project METSOFC and the Danish National Advanced Technology Foundation, which previously showed a fair long-term stability over several $1000 \mathrm{~h}$ at $650^{\circ} \mathrm{C}$ and performance at intermediate temperatures similar or better than conventional Ni-based anode supported cells, was optimized with respect to the corrosion resistance of the metal support, the interdiffusion barrier layer at the MIEC-cathode/electrolyte-interface and the cathode.

A detailed electrochemical analysis of the state of the art (type A) and optimized cells (type B) by impedance spectroscopy, an impedance data analysis by the distribution of relaxation times (DRT) and a subsequent CNLS- fitting with a physically motivated equivalent circuit enabled us to deconvolute the polarization mechanisms.

The impedance analysis showed, that the improvement of the metal support with respect to corrosion resistance did not affect the gas diffusion resistance of the substrate. Despite of the coarser microstructure exhibiting a reduced internal surface area and hence an improved corrosion behavior, the gas transport to the anode functional layer was not affected.

The application of an LSC/CGO-composite cathode instead of the previously applied LSCF/CGO-composite cathode resulted in a decrease of the cathode polarization resistance from 112 to $57 \mathrm{~m} \Omega \cdot \mathrm{cm}^{2}$ at $650^{\circ} \mathrm{C}$.

The major improvement in performance was achieved by implementing a dense interdiffusion barrier layer at the MIEC-cathode/electrolyte-interface. By preventing the formation of an insulating zirconate phase the related polarization process exhibiting an area specific resistance of $427.5 \mathrm{~m} \Omega \cdot \mathrm{cm}^{2}$ at $650^{\circ} \mathrm{C}$ could be avoided in the type B cells.

\section{Acknowledgement}

Financial support by Topsoe Fuel Cell, the EU project FP7-211940 (METSOFC), and The Danish National Advanced Technology Foundation is gratefully acknowledged.

\section{References}

[1] M. C. Tucker, G. Y. Lau, C. P. Jacobson, L. C. DeJonghe and S. J. Visco, "Performance of metal-supported SOFCs with infiltrated electrodes", Journal of Power Sources 171, pp. 477-482 (2007).

[2] M. C. Tucker, "Progress in metal-supported solid oxide fuel cells: A review", Journal of Power Sources 195, pp. 4570-4582 (2010).

[3] R. Vassen, D. Hathiramani, J. Mertens, V. A. C. Haanappel and I. C. Vinke, "Manufacturing of high performance solid oxide fuel cells (SOFCs) with atmospheric plasma spraying (APS)", Surface and Coatings Technology 202, pp. 499-508 (2007).

[4] G. Schiller, R. H. Henne, M. Lang, R. Ruckdäschel and S. Schaper, "Development of vacuum plasma sprayed thin-film SOFC for reduced operating temperature", Fuel Cells Bulletin 3, pp. 7-12 (2000).

[5] Z. Wang, J. O. Berghaus, S. Yick, C. Deces-Petit, W. Qu, R. Hui, R. Maric and D. Ghosh, "Dynamic evaluation of low-temperature metal-supported solid oxide fuel cell oriented to auxiliary power units", Journal of Power Sources 176, pp. 90-95 (2008). 
[6] R. Hui, J. O. Berghaus, C. Deces-Petit, W. Qu, S. Yick, J. G. Legoux and C. Moreau, "High performance metal-supported solid oxide fuel cells fabricated by thermal spray", Journal of Power Sources 191, pp. 371-376 (2009).

[7] S. Hui, D. Yang, Z. Wang, S. Yick, C. Deces-Petit, W. Qu, A. Tuck, R. Maric and D. Ghosh, "Metal-supported solid oxide fuel cell operated at 400 to $600{ }^{\circ} \mathrm{C}$ ", Journal of Power Sources 167, pp. 336-339 (2007).

[8] M. C. Tucker, G. Y. Lau, C. P. Jacobson, L. C. DeJonghe and S. J. Visco, "Stability and robustness of metal-supported SOFCs", Journal of Power Sources 175, pp. 447451 (2008).

[9] Y. B. Matus, L. C. de Jonghe, C. P. Jacobson and S. J. Visco, "Metal-supported solid oxide fuel cell membranes for rapid thermal cycling", Solid State Ionics 176, pp. 443449 (2005).

[10] P. Blennow, J. Hjelm, T. Klemensoe, S. Ramousse, A. Kromp, A. Leonide and A. Weber, "Manufacturing and characterization of metal-supported solid oxide fuel cells", J. Power Sources 196, pp. 7117-7125 (2011).

[11] T. Klemensoe, J. Nielsen, P. Blennow, A. H. Persson, T. Stegk, B. H. Christensen and S. Soenderby, "High performance metal-supported solid oxide fuel cells with Gddoped ceria barrier layers", Journal of Power Sources 196, pp. 9459-9466 (2011).

[12] P. Blennow, J. Hjelm, T. Klemensoe, A. H. Persson, S. Ramousse and M. Mogensen, "Planar Metal-Supported SOFC with Novel Cermet Anode", Fuel Cells 11, pp. 661668 (2011).

[13] A. Weber, A. C. Müller, D. Herbstritt and E. Ivers-Tiffée, "Characterization of SOFC Single Cells", in H. Yokokawa and S. C. Singhal (Eds.), Proceedings of the Seventh International Symposium on Solid Oxide Fuel Cells (SOFC-VII), pp. $952-962$ (2001).

[14] A. Leonide, V. Sonn, A. Weber and E. Ivers-Tiffée, "Evaluation and Modelling of the Cell Resistance in Anode Supported Solid Oxide Fuel Cells", ECS Trans. 7, pp. 521531 (2007).

[15] H. Schichlein, A. C. Müller, M. Voigts, A. Krügel and E. Ivers-Tiffée, "Deconvolution of electrochemical impedance spectra for the identification of electrode reaction mechanisms in solid oxide fuel cells", Journal of Applied Electrochemistry 32, pp. 875-882 (2002).

[16] P. Blennow, J. Hjelm, T. Klemensoe, S. Ramousse, A. Kromp, A. Leonide and A. Weber, "Manufacturing and Characterization of Metal Supported SOFCs", in J. T. S. Irvine and U. Bossel (Eds.), Proceedings of the 9th European Solid Oxide Fuel Cell Forum, pp. 16-1-16-19 (2010).

[17] A. Leonide, V. Sonn, A. Weber and E. Ivers-Tiffée, "Evaluation and modeling of the cell resistance in anode-supported solid oxide fuel cells", J. Electrochem. Soc. 155, p. B36-B41 (2008).

[18] A. Leonide, Y. Apel and E. Ivers-Tiffée, "SOFC Modeling and Parameter Identification by means of Impedance Spectroscopy", ECS Trans. 19, pp. 81-109 (2009). 